University of Nebraska - Lincoln

DigitalCommons@University of Nebraska - Lincoln

Agronomy \& Horticulture -- Faculty Publications

Agronomy and Horticulture Department

6-4-2016

\title{
Long-term Sandhills prairie responses to precipitation, temperature, and cattle stocking rate
}

John A. Guretzky

University of Nebraska-Lincoln, jguretzky2@unl.edu

Cheryl Dunn

University of Nebraska-Lincoln, cdunn3@unl.edu

Heidi L. Hillhouse

University of Nebraska-Lincoln, hhillhouse3@unl.edu

Follow this and additional works at: https://digitalcommons.unl.edu/agronomyfacpub

Part of the Agricultural Science Commons, Agriculture Commons, Agronomy and Crop Sciences Commons, Botany Commons, Horticulture Commons, Other Plant Sciences Commons, and the Plant Biology Commons

Guretzky, John A.; Dunn, Cheryl; and Hillhouse, Heidi L., "Long-term Sandhills prairie responses to precipitation, temperature, and cattle stocking rate" (2016). Agronomy \& Horticulture -- Faculty Publications. 1033.

https://digitalcommons.unl.edu/agronomyfacpub/1033

This Article is brought to you for free and open access by the Agronomy and Horticulture Department at DigitalCommons@University of Nebraska - Lincoln. It has been accepted for inclusion in Agronomy \& Horticulture -Faculty Publications by an authorized administrator of DigitalCommons@University of Nebraska - Lincoln. 


\title{
Long-term Sandhills prairie responses to precipitation, temperature, and cattle stocking rate
}

\author{
John A. Guretzky, Cheryl Dunn, and Heidi Hillhouse \\ Department of Agronomy and Horticulture, University of Nebraska-Lincoln \\ Corresponding author - J. A. Guretzky, Department of Agronomy and Horticulture, \\ University of Nebraska-Lincoln, Lincoln, NE 68583-0915, USA, e-mail jguretzky2@unl.edu
}

\begin{abstract}
Understanding of Sandhills prairie, the most expansive sand dune region stabilized by perennial grasses in the Western Hemisphere, is limited by lack of long-term vegetation data. We used a 26-year dataset to evaluate Sandhills prairie responses to yearto-year variation in precipitation, temperature, and cattle stocking rate. Basal cover, a measurement that is constant seasonally and used to detect long-term changes in bunchgrass vegetation, was measured in 38-40 permanent plots positioned along four transects spanning 769 ha from 1979 to 2007. Across this period, total basal cover averaged $2.4 \%$ and was dominated by warm-season grasses $(81.1 \%)$. Schizachyrium scoparium (little bluestem), the dominant warmseason bunchgrass, consisted of $60.0 \%$ relative basal cover. Warm-season grass and total basal cover responded positively to lag 3-year growing season precipitation indicating delayed responses to improved growing season conditions, but these variables also were positively associated with stocking rate. The positive responses may be due to slow spread of warmseason grasses by vegetative structures in response to favorable growing conditions in light to moderately stocked rangeland. Despite its dominance, however, warm-season grass cover had no influence on cover of other functional groups providing weak support for
\end{abstract}

competition as regulator of Sandhills prairie composition. Forb cover was best related in a negative manner to 3-year running mean total precipitation, a surprising result that maybe signaling factors governing basal responses in prairie remain largely unresolved. Woody species cover, however, was positively associated with mean growing season temperatures indicating potential of these to spread under warming scenarios.

Keywords: Basal cover, Climate change, Cool-season grasses, Grasslands, Great plains, Warm-season grasses

\section{Introduction}

Climate variability and change is expected to alter ecosystem structure and function (Easterling et al. 2000; Weltzin et al. 2003; Smith et al. 2009; Cleland et al. 2013; Hoover et al. 2014). A hierarchy of responses from changes in plant growth and function, to simplification of plant communities, and invasion of exotic species are possible (Tilman and El Haddi 1992; Smith et al. 2009). These responses by the plant community are dependent on the magnitude, duration, and timing of the climatic stress (Hoover et al. 2014). Periods of below average precipitation or drought in the 
past have led to a decrease in basal cover of dominant warm-season bunchgrasses (Weaver and Albertson 1936; Herbel et al. 1972; Fuhlendorf and Smeins 1997; Biondini et al. 1998). Resilience, i.e., capacity for recovery of ecosystem function (Hoover et al. 2014), however, was demonstrated when subsequent increases in growing season rainfall returned basal cover of the dominant warm-season grass species to near pre-drought levels despite changes in plant community composition (Herbel et al. 1972; Fuhlendorf and Smeins 1997; Biondini et al. 1998).

In the central U.S., the presence of dominant perennial warm-season grasses enhances resilience to climatic extremes (Hoover et al. 2014) through investment in traits such as belowground reserves that supply carbohydrate when photosynthesis and growth is limited and basal meristems that remain protected from disturbances such as grazing (Coughenour 1985; Ott and Hartnett 2011). Warm-season grasses also adjust osmotically, fold or roll leaves, and modify stomatal conductance to maintain photosynthetic and metabolic activities during low moisture stress (Sala et al. 1982; Knapp 1985). Deeply penetrating, widely branching, and depth-segregated rooting systems also help perennial warm-season grasses tolerate drought (Weaver and Albertson 1936), and spread of vegetative structures contributes to population recovery after drought (Hendrickson and Briske 1997; Benson et al. 2004).

Although there has been much focus on evaluating grassland responses to extreme climatic events in recent years (Fay et al. 2002, 2003, 2008; Knapp et al. 2002; Heisler-White et al. 2008; Hoover et al. 2014), the presence of long-term datasets also can be valuable in assessing plant community responses to climate variability (Sherry et al. 2012), but these responses have not been examined in Nebraska Sandhills prairie. The Sandhills, $\mathrm{a} \approx 4.8$ million ha region in north central Nebraska, is the most expansive sand dune region in the Western Hemisphere currently stabilized by perennial warm-season grasses and supported by soils that rapidly absorb precipitation (Bleed and Flowerday 1998; Schacht et al. 2000). The Sandhills supports about 720 vascular plant species, including 670 native species and 50 introduced species (Kaul 1998), and is one of the largest, contiguous grasslands remaining in the Great Plains region of North America (Samson et al. 2004). Although prairie vegetation currently provides stability, wide-scale wind erosion occurred during the Holocene, and it has been projected that a shift toward a warmer climate may cause grassland death and allow dunes to move (Mangan et al. 2004).

In 1926, a long-term study was established at the Nebraska National Forest to investigate Sandhills prairie responses to cattle grazing. At the time, grazing was being used to shift prairie vegetation from a taller, S. scoparium, to a shorter, Bouteloua hirsuta (hairy grama), dominated bunchgrass community to create a natural firebreak and protect adjacent forest from wildfire. Frequency of occurrence of plant species among permanent plots was evaluated across a period spanning from 1926 to 2004 and reported in Stubbendieck and Tunnell (2008). However, data collected on plant basal cover from 1979 to 2007 have not been summarized, analyzed, or reported. Basal cover, a measure of ground area covered by crowns and shoots, has often been evaluated in long-term studies (Albertson and Tomanek 1965; Herbel et al. 1972; Fuhlendorf and Smeins 1997; Fuhlendorf et al. 2001; Gillen and Sims 2006) and is considered an appropriate metric to evaluate disturbances related to weather functions in bunchgrass-dominated communities because of its stability within and across growing seasons (Herbel et al. 1972; Havstad and Herrick 2003) and power to detect ecologically significant changes (Brady et al. 1995).

Our objectives were to use the long-term data on basal cover to describe relative species composition and examine responses of most abundant plant species and functional groups in Sandhills prairie to yearto-year variation in precipitation, temperature, and cattle stocking rate. We hypothesized that (1) total basal cover would increase with greater temperature and precipitation due to positive responses of warmseason grasses (e.g., Knapp 1985); (2) perennial forb cover would be resistant to precipitation and temperature variability because forbs can obtain water from different soil depths (e.g., Nippert and Knapp 2007); (3) an increase in cattle stocking rate would reduce warm-season grass cover due to negative grazing effects on S. scoparium (e.g., Butler and Briske 1988; Derner et al. 1994); and (4) an increase in S. scoparium would negatively affect cover of other species due to greater competition as bunchgrasses concentrate soil resources and occupy space (e.g., Derner and Briske 2001). 


\section{Methods}

\section{Study area}

The study was located in Sandhills prairie on sands ecological sites at the Nebraska National Forest Bessey Ranger District-Bessey Unit $\left(41^{\circ} 52^{\prime} \mathrm{N} ; 100^{\circ} 21^{\prime} \mathrm{W}\right), 1.6$ $\mathrm{km}$ west of Halsey in Thomas County, NE (Fig. 1). The Bessey Unit encompassed 36,638 ha including 7913 ha of the largest plantation forests of Pinus ponderosa (ponderosa pine) and Juniperus virginiana (eastern red cedar) in the United States (US Forest Service
2009). Grassland consisted of 28,139 ha of the Bessey Unit and was characterized historically as a mixture of tallgrass and mixed-grass prairie (Pool 1913; Tolstead 1942; Schacht et al. 2000). Soils were Valentine fine sands with a parent material of quartz sand (Keech and Bentall 1971).

Established in 1926, the permanently marked plots in this study were originally used to evaluate the feasibility of using heavy grazing (i.e., a cattle stocking rate of 2.2 animal unit months (AUM) ha ${ }^{-1}$, where one $\mathrm{AU}=450 \mathrm{~kg}$ live weight) to establish a firebreak near the forest. After being monitored through 1938 and

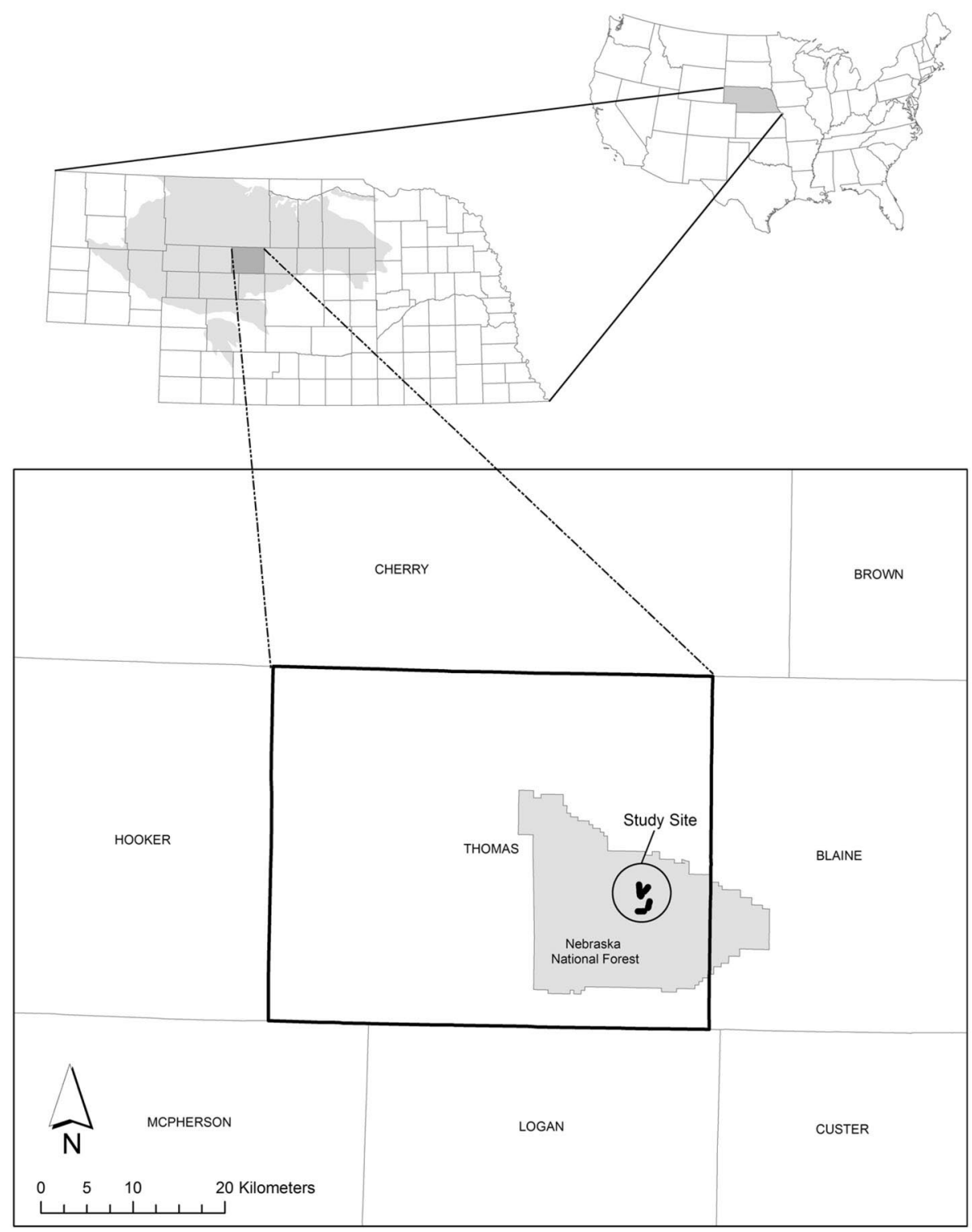

Figure 1 Location of long-term monitoring plots in Sandhills prairie at the Nebraska National Forest in Thomas County, Nebraska. The extent of Sandhills prairie in Nebraska is indicated by the light gray shading in the statewide map 
briefly by the US Forest Service in the 1940s, data were not collected from the plots until 1979 when this study was initiated. The 48 plots established in 1926 were arranged along four transects covering a range of topographic positions (dune tops, slopes, and interdunes/terraces) and slope directions (Fig. 2). By 1979, eight plots could no longer be located, and some of the remaining plots were difficult to find consistently. Of the remaining 40 plots, twenty-nine had data collected every year, eight were missing data from either 1 or 2 years, and three were missing data from more than 2 years. Most of the plots were in Valentine fine sand with rolling and hilly, 9-6o \% slopes with the exception of half of transect 4 which was in Valentine fine sand with rolling, 9-24 $\%$ slopes (Fig. 2). Heavy grazing following establishment of the plots in 1926 was successful in shifting botanical composition, but due to increased weed invasion and improvements in fire control equipment, a moderate grazing regime was implemented and $S$. scoparium was again the dominant species by 1979
(Stubbendieck and Tunnell 2008). From 1979 to 2007, all plots experienced the same cattle stocking rate each year $\left(\right.$ mean $\left.=0.85 \mathrm{AUM} \mathrm{ha}^{-1}\right)$, but this varied with grazing allotments established annually between ranchers and the U.S. Forest Service and was not closely associated with climatic variables (Appendix in Table 5).

\section{Data collection and analysis}

Basal cover was measured annually in August or September 1979-2007, except from 2000 to 2002 (Appendix in Table 4). Each plot had two permanent markers that allowed square frames to be consistently placed on the same $1-\mathrm{m}^{2}$ area. After placing a $1-\mathrm{m}^{2}$ square frame in the designated position, basal cover was measured using the line intercept method. A ruler was placed across the frame at nine pre-determined locations for a maximum basal cover of $9000 \mathrm{~mm}$. Basal cover was recorded by measuring the distance $(\mathrm{mm})$ in which the basal part of the
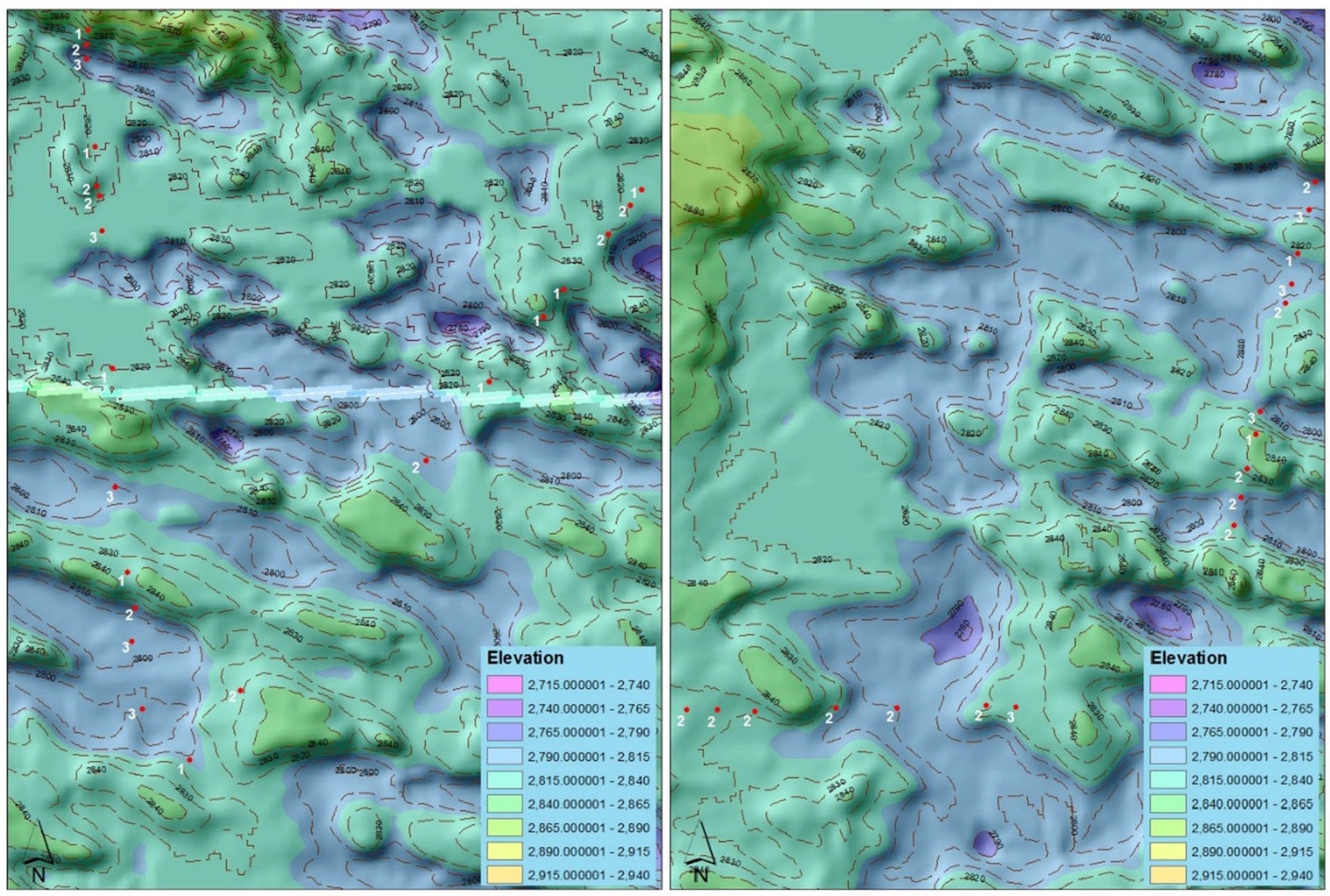

Figure 2 Distribution of long-term monitoring plots along four transects traversing dune top (1), slope (2), and interdunal/ terrace (3) topographic positions in Sandhills prairie at the Nebraska National Forest in Thomas County, Nebraska 
plant intersected the ruler. Through the study period, 92 plant species were recorded, but most of these species were absent from plots across several years. The 14 species that made up $95 \%$ of the total cover and present in nearly all 25 years of the study (Appendix in Table 4) were used in analyses to describe relative species composition and examine relationships of mean plot basal cover to climatic and stocking rate variables (Appendix in Table 5). Relationships of mean plot basal cover to climatic and stocking rate variables also were examined by functional groups which included warm season grasses, cool-season grasses, sedges, succulents, forbs, and woody species computed from the 92 species recorded in the 26 years of the study.

A series of stepwise multiple regression analyses were used to examine relationships of actual basal cover of the 14 most abundant species, their functional groups, and total basal cover with climate data, cattle stocking rates, and basal cover of $S$. scoparium and warm-season grasses as a whole based on a priori knowledge of their dominance in Sandhills prairie (Pool 1913; Schacht et al. 2000; Stubbendieck and Tunnell 2008). The use of stepwise regressions helped eliminate multicollinearity issues with the climate data by adding independent variables one at a time. The model with the lowest Akaike's Information Criteria value was selected as the most suitable model out of all the models generated. Annual and monthly climate data were obtained from the National Climatic Data Center (2013) and the High Plains Regional Climate Center (2012). Weather stations were located at or within $48 \mathrm{~km}$ of Halsey, NE. Climatic variables included total precipitation (Total PPT), mean annual temperature (Mean Ann Temp), minimum temperature (Min Temp), maximum temperature (Max Temp), and the Palmer drought severity index (PDSI) which combines precipitation and temperature and produces a number that is either negative or positive relating to dry or wet periods, respectively (Heddinghaus and Sabol 1991). The growing season (April-September) means of most variables were separated from the data, and total precipitation was also divided into early growing season (April-June) and late growing season (July-Sept). Total precipitation during the growing season of the previous year (Lag 1-year PPT), a 3 year lag (Lag 3-year PPT), and a three-year running mean (3-year running mean PPT), as well as a three-year lag late growing season (July-Sept) were also added. All statistical analyses were conducted with SPSS statistical package (version 22.0, SPSS Incorporated, Chicago, IL). Normal distribution of data was assessed by a Kolmogorov-Smirnov goodness of fit test. Statistical significance was declared at $\mathrm{P} \leq 0.05$.

\section{Results}

\section{Relative species composition}

Total basal cover had a mean \pm SD of $2.4 \pm 1.0 \%$ across the study period of 1979-2007. Of this cover, $81.1 \pm 9.6$ and $8.9 \pm 7.3 \%$ consisted of warm- and cool-season grasses, respectively. Schizachyrium scoparium and $B$. hirsuta were the most abundant warm season grasses, and Dichanthelium oligosanthes (Scribners panicum) and Hesperostipa comata (needle- andthread) were the most abundant cool-season grasses (Table 1). A total of 45 species of forbs were recorded with a combined basal cover of $1.9 \pm 1.5 \%$, and woody species, which included subshrubs, shrubs, and a tree, had a combined basal cover of $1.6 \pm 1.2 \%$. Ambrosia psilostachya (western ragweed) comprised approximately half of the forb cover, while Rosa arkansana (prairie rose) and Amorpha canescens (leadplant) were the most abundant woody plants (Table 1 ). Two genera of sedges, Carex and Cyperus, comprised $4.5 \pm 2.7 \%$ of basal cover while succulents, represented by three species in the Opuntia genus, had a basal cover of $2.1 \pm$ $2.5 \%$. Opuntia fragilis (little prickly pear) accounted for over half of the succulent cover.

\section{Climatic conditions and cattle stocking rate}

Climatic variables that had the greatest influence on basal cover included mean growing season (AprilSeptember) temperature and precipitation, mean growing season maximum temperature, mean dormant season (October-March) temperature, mean late growing season (July-September) precipitation, and total annual precipitation (Fig. 3). From 1979 to 2007 , mean \pm SD growing season temperature was $17.5 \pm 1.0$ _C while mean \pm SD growing season maximum temperature was $25.2 \pm 1.3{ }^{\circ} \mathrm{C}$. Meanwhile, growing season precipitation accounted for the majority of total annual precipitation (Fig. 3), which averaged $440 \pm$ 90 and $578 \pm 116 \mathrm{~mm}$, respectively. Most precipitation fell early in the growing season (April-June) but late growing season precipitation had more impact on basal cover responses. Across the study, PDSI had a mean \pm SD of $1.9 \pm 2.7$ indicating a slightly wetter period overall (Appendix in Table 5). 
Table 1 Relative basal cover of plant species that occurred in C50\% of plots in Sandhills prairie at the Nebraska National Forest Bessey Ranger District near Halsey, Nebraska from 1979 to 2007

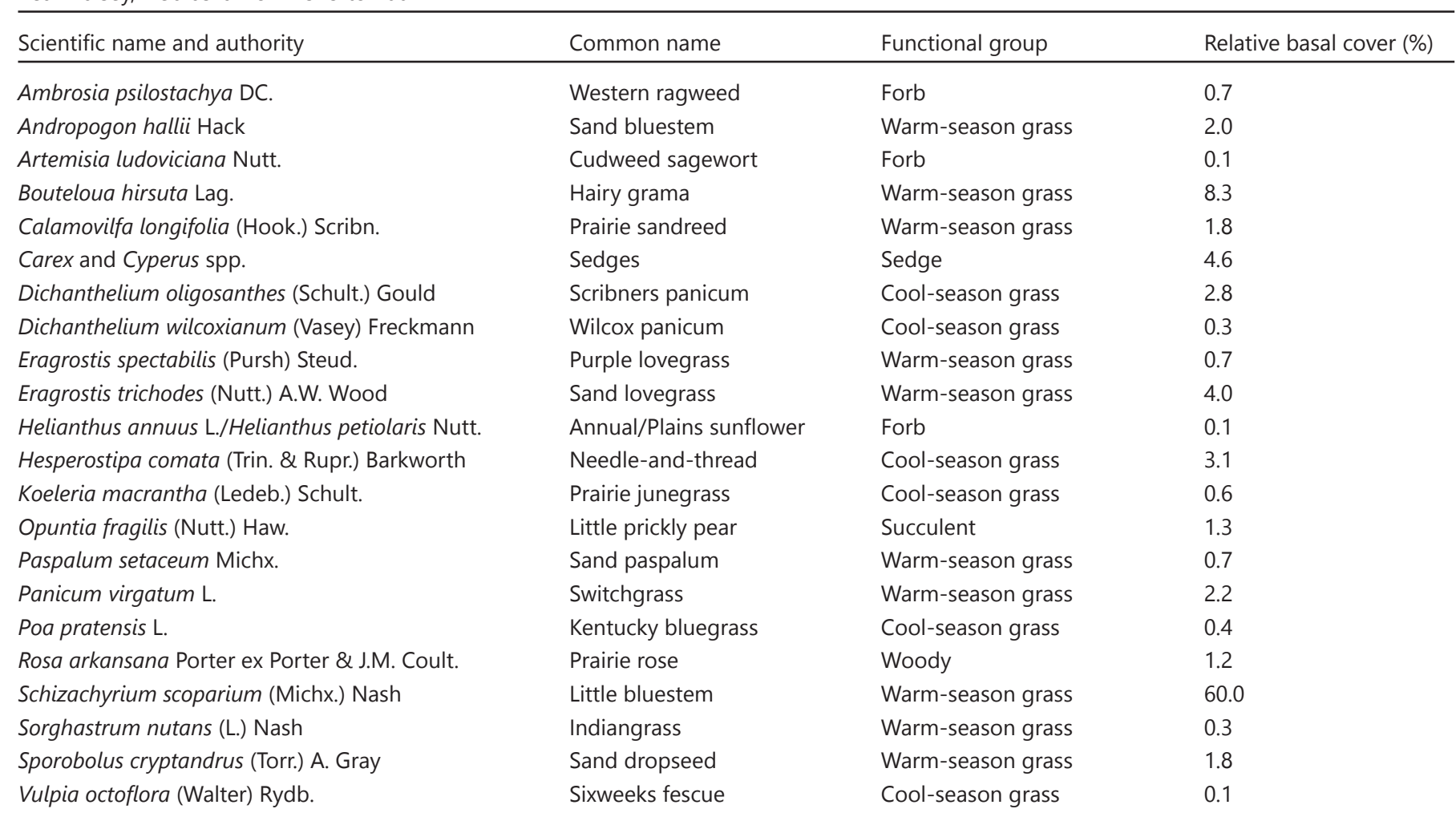

\section{Basal cover responses}

Climatic variables explained basal cover responses of 10 of 14 species (Table 2). For these ten species, the variation explained (adjusted $\mathrm{R}^{2}$ ) ranged from 18.1 to $68.1 \%$. Basal cover of $S$. scoparium, despite being the dominant species and highly competitive for soil resources (Derner and Briske 2001), did not show a significant response to climatic variables. Schizachyrium scoparium only explained basal cover responses of two species; S. scoparium was positively correlated with Paspalum setaceum (sand paspalum) basal cover and negatively correlated with $R$. arkansana basal cover. Meanwhile, growing season and total precipitation were negatively related to basal cover responses of several species including $A$. psilostachya, B. hirsuta, Calamovilfa longifolia (prairie sandreed), Eragrostis trichodes (sand lovegrass), and $H$. comata as demonstrated by significant b coefficients for the 3-year running means for April-September, July- September, and total precipitation, as well as simply total precipitation (Table 2). Late growing season precipitation, both in terms of lag 3-year and total precipitation, also contributed to improved understanding of $B$. hirsuta responses.

Either current year mean April-September temperature or mean April-September maximum temperature were strong positive predictors of Andropogon hallii (sand bluestem), B. hirsuta, R. arkansana, and Sporobolus cryptandrus (sand dropseed) basal cover. Opuntia fragilis was the only species that had a negative response to growing season maximum temperature. However, as PDSI decreased, meaning the combination of precipitation and temperature was having a drying effect, $O$. fragilis and $P$. virgatum increased in 

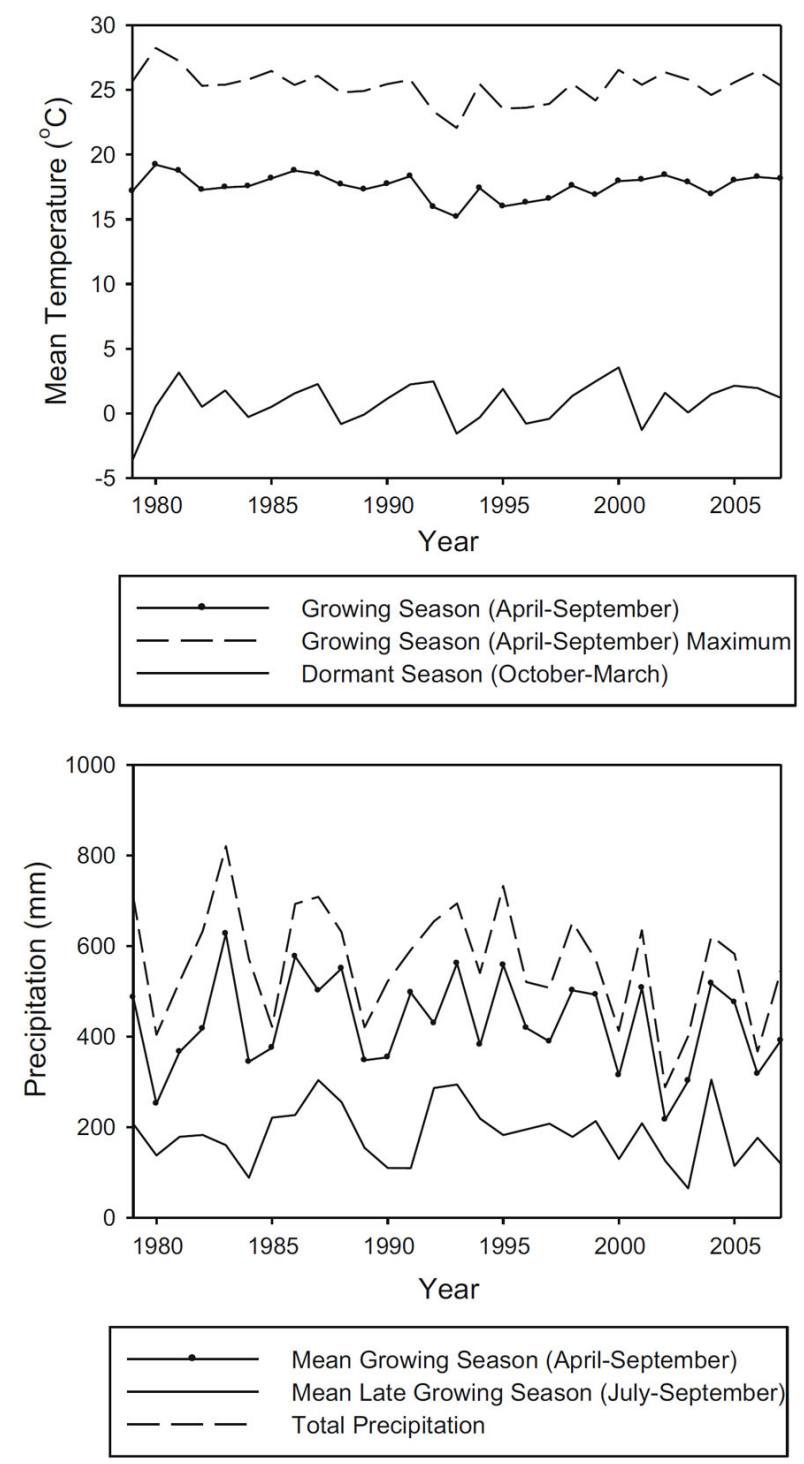

Figure 3 Temperature and precipitation variables that influenced plant species and functional group composition in Sandhills prairie at the Nebraska National Forest Bessey Ranger District near Halsey, Nebraska from 1979 to 2007

basal cover, while $H$. comata decreased. In two models, stocking rate was found to be a strong predictor variable (Table 2). Stocking rate was negatively correlated with $O$. fragilis cover but positively correlated with A. psilostachya cover.

Climatic variables and stocking rate explained from o to $31.4 \%$ of functional group variation (Table 3 ). The 3-year running mean total precipitation had a negative relationship with forb basal cover, while growing season temperature was positively related to woody species basal cover. Meanwhile, as PDSI decreased, succulent basal cover increased. Basal cover of warmseason grasses had the same predictor variables as total cover, responding positively to stocking rate and lag 3-year growing season precipitation. Basal cover of cool-season grasses was negatively influenced by an increase in total precipitation, but basal cover of sedges showed no response to climatic variables or stocking rate.

\section{Discussion}

\section{Relative species composition}

Relative species composition compared well with historical vegetation composition on sands ecological sites, indicating the prairie was in good to excellent condition (Pool 1913; Tolstead 1942; Schacht et al. 2000; Stubbendieck and Tunnell 2008). Principal dominants historically included tall and mid-height warm-season grasses including $A$. hallii, $C$. longifolia, and $S$. scoparium. Subdominant grass species included Achnatherum hymenoides (Indian ricegrass), $D$. oligosanthes, $H$. comata, $H$. spartea (porcupinegrass), P. virgatum, S. cryptandrus, and either B. hirsuta or B. gracilis (blue grama). With exception of A. hymenoides and B. gracilis, all of these species were found in the prairie. Areas where the prairie differed from the historical vegetation composition was in terms of warm-season grass and forb cover. Historically, the plant community consisted of $85 \%$ grasses and grasslike plants, $10 \%$ forbs, and $5 \%$ shrubs (including succulents) by weight (USDA-NRCS 2016). In contrast, average basal cover in this Sandhills prairie consisted of $95 \%$ grasses and grass-like plants, $2 \%$ forbs, and $4 \%$ shrubs (including succulents). Of warm-season grasses, $60 \%$ of relative basal cover was S. scoparium compared to $2 \%$ each for $A$. hallii and $C$. longifolia, which may be artifacts of sampling methods that elevate measures of crown-forming bunchgrasses such as $S$. scoparium relative to rhizomatous species with widely dispersed tiller populations (Cullan et al. 1999). With regard to forbs, Artemisia dracunculus (tarragon) and Cirsium sp. (thistle) were not found in the prairie but were there historically (USDANRCS 2016).

Topography as it relates to soil depth and moisture availability also can influence Sandhills prairie composition (Schacht et al. 2000). Vegetation surveys have found the presence of $S$. scoparium and cool 
Table 2 Stepwise multiple regressions for basal cover of plant species in Sandhills prairie from 1979 to 2007 relative to variables including Schizachyrium scoparium (SCSC) cover, precipitation (PPT), temperature (Temp), and the Palmer drought severity index (PDSI)

\begin{tabular}{|c|c|c|c|c|c|c|c|}
\hline Ambrosia psilostachya & 0.542 & 10.86 & $<0.001$ & Constant & -313.427 & 0.168 & \\
\hline Andropogon hallii & 0.28 & 10.714 & 0.003 & $\begin{array}{l}\text { Constant } \\
\text { Mean Apr-Sept temp }\end{array}$ & $\begin{array}{r}-1749.833 \\
29.868\end{array}$ & $\begin{array}{l}0.006 \\
0.003\end{array}$ & 0.556 \\
\hline Bouteloua hirsuta & 0.681 & 11.679 & $<0.001$ & $\begin{array}{l}\text { Constant } \\
\text { Mean Apr-Sept max temp } \\
\text { 3-year running mean PPT } \\
\text { Apr-Sept } \\
\text { Mean Oct-Mar temp } \\
\text { Lag 3-year PPT July-Sept } \\
\text { Total PPT July-Sept }\end{array}$ & $\begin{array}{r}-7166.763 \\
192.235 \\
-187.918 \\
\\
-147.778 \\
92.783 \\
61.446\end{array}$ & $\begin{array}{r}0.017 \\
<0.001 \\
<0.001 \\
\\
<0.001 \\
0.004 \\
0.050\end{array}$ & $\begin{array}{r}0.787 \\
-0.732 \\
-0.720 \\
0.447 \\
0.285\end{array}$ \\
\hline Carex spp. & NS & & & & & & \\
\hline Dichanthelium oligosanthes & NS & & & & & & \\
\hline Eragrostis trichodes & 0.435 & 10.635 & 0.001 & $\begin{array}{l}\text { Constant } \\
\text { 3-year running mean PPT } \\
\text { July-Sept } \\
\text { Lag 3-year PPT Apr-Jun }\end{array}$ & $\begin{array}{r}965.001 \\
-58.401 \\
\\
34.196\end{array}$ & $\begin{array}{l}0.001 \\
0.001 \\
0.001\end{array}$ & $\begin{array}{r}-0.627 \\
0.610\end{array}$ \\
\hline Hesperostipa comata & 0.582 & 9.701 & $<0.001$ & $\begin{array}{l}\text { Constant } \\
\text { Total PPT } \\
\text { Mean PDSI } \\
\text { 3-year running mean total PPT } \\
\text { Lag 1-year PPT Apr-Sept }\end{array}$ & $\begin{array}{r}2421.465 \\
-39.860 \\
56.296 \\
-45.471 \\
-19.385\end{array}$ & $\begin{array}{r}<0.001 \\
<0.001 \\
0.001 \\
0.001 \\
0.016\end{array}$ & $\begin{array}{r}-0.892 \\
0.750 \\
-0.637 \\
-0.393\end{array}$ \\
\hline Panicum virgatum & 0.181 & 6.527 & 0.017 & $\begin{array}{l}\text { Constant } \\
\text { Mean PDSI }\end{array}$ & $\begin{array}{l}214.141 \\
-22.007\end{array}$ & $\begin{array}{r}<0.001 \\
0.017\end{array}$ & -0.462 \\
\hline Paspalum setaceum & 0.141 & 5.114 & 0.033 & $\begin{array}{l}\text { Constant } \\
\text { SCSC cover }\end{array}$ & $\begin{array}{r}20.494 \\
0.008\end{array}$ & $\begin{array}{l}0.344 \\
0.033\end{array}$ & 0.419 \\
\hline Rosa arkansana & 0.402 & 9.420 & 0.001 & $\begin{array}{l}\text { Constant } \\
\text { Mean Apr-Sept temp } \\
\text { SCSC cover }\end{array}$ & $\begin{array}{r}-960.023 \\
17.054 \\
-0.006\end{array}$ & $\begin{array}{l}0.007 \\
0.003 \\
0.034\end{array}$ & $\begin{array}{r}0.523 \\
-0.353\end{array}$ \\
\hline Schizachyrium scoparium & NS & & & & & & \\
\hline Sporobolus cryptandrus & 0.201 & 7.279 & 0.013 & $\begin{array}{l}\text { Constant } \\
\text { Mean Apr-Sept max temp }\end{array}$ & $\begin{array}{r}-2726.764 \\
37.272\end{array}$ & $\begin{array}{l}0.018 \\
0.013\end{array}$ & 0.482 \\
\hline
\end{tabular}

In these regressions, the adjusted $R^{2}$ described fit of the model to the data, the first $P$ value indicated significance of the model, $B$ was the unstandardized coefficient, the second $P$ value indicated significance of independent variable in the model, and $\beta$ was the standardized coefficient. 
Table 3 Stepwise multiple regression results for basal cover of functional groups in Sandhills prairie from 1979 to 2007 relative to variables including warm-season grass cover, precipitation (PPT), temperature (temp), and the Palmer drought severity index (PDSI)

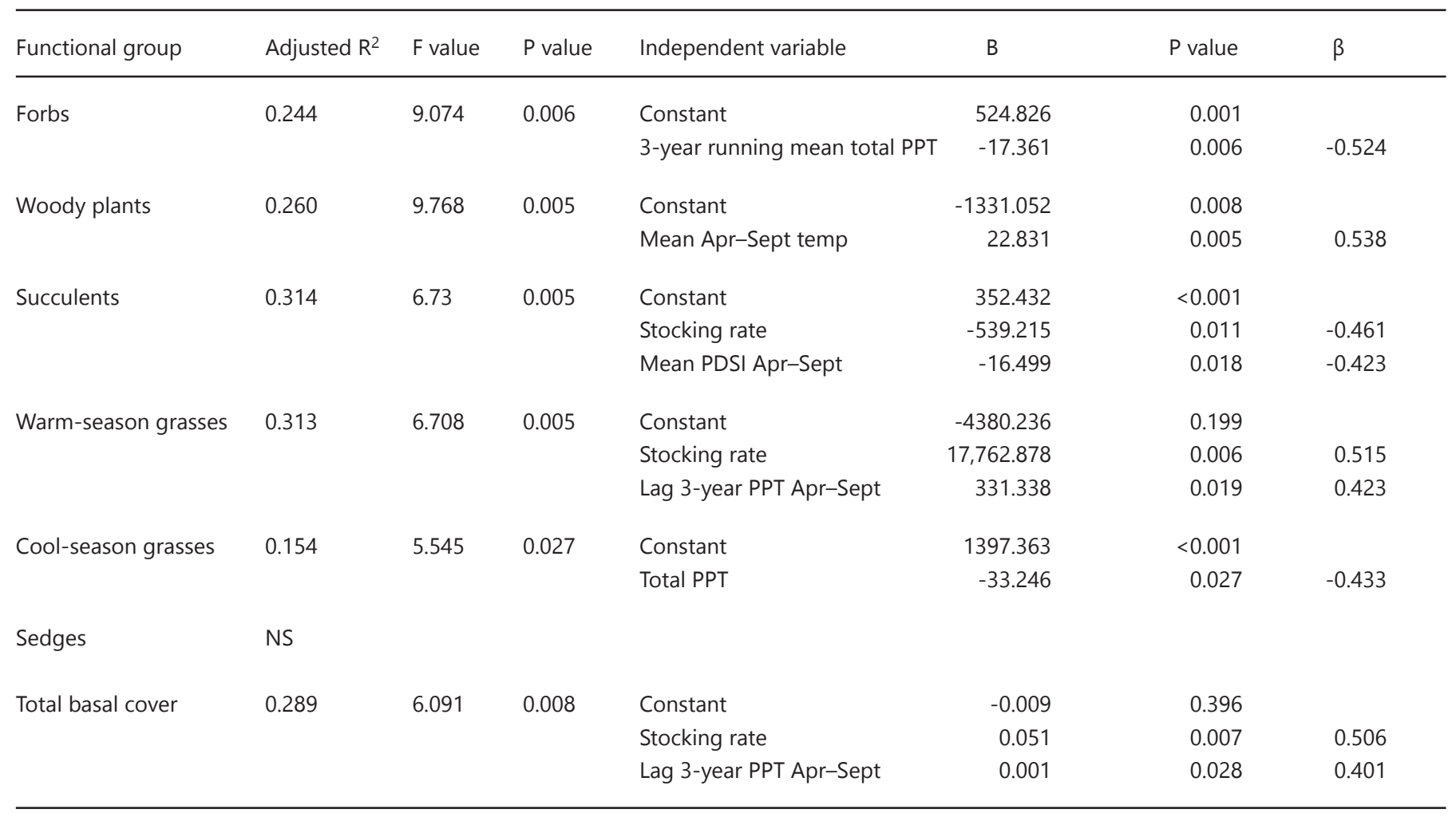

In these regressions, the adjusted $R^{2}$ described fit of the model to the data, the first $P$ value indicated significance of the model, $B$ was the unstandardized coefficient, the second $P$ value indicated significance of independent variable in the model, and $\beta$ was the standardized coefficient.

season grasses such as $H$. comata and Koeleria macrantha (prairie junegrass) to be positively associated with north-facing slopes, while warm-season grasses such as $C$. longifolia and $A$. hallii were positively associated with south-facing slopes (Schacht et al. 2000). While some of our species were aligned with the same topographic positions [e.g., B. hirsuta and dunetops; Poa pratensis (Kentucky bluegrass) and interdunes] as in Schacht et al. (2000), limitations on plot numbers assigned to various topographic positions prevented a robust analysis of plant species-topographic associations in our study (data not shown).

\section{Basal cover responses to precipitation and temperature}

Seasonal or total precipitation variables influenced basal cover responses of 5 of the 14 species we analyzed, as well as total basal cover, but for the most part, species responses were individualistic and noisy as observed in other long-term studies (e.g., Fuhlendorf and Smeins 1997; Gillen and Sims 2006; Tilman et al. 2006; Adler and HilleRisLambers 2008). Arid and semi-arid grasslands often contain a large number of annual species that are particularly responsive 
to changes in precipitation (O'Connor and Roux 1995; Hobbs et al. 2007; Cleland et al. 2013). Of the 9 species that did not respond to year-to-year fluctuations in seasonal or total precipitation, 7 of these were grasses or sedges and their basal responses were likely delayed by slow spread and contraction of vegetative structures and crowns in response to current climatic conditions. As a group, warm-season grass and total basal cover responded positively to 3-year lag growing season precipitation, results supportive of our first hypothesis and other long-term studies that have found basal cover of perennial warm-season grasses to be responsive to changes in precipitation (Albertson and Tomanek 1965; Fuhlendorf et al. 2001), though responses depended on a lag period (e.g., Sherry et al. 2012).

Temperature variability influenced basal cover responses of 6 of the 14 species but not total basal cover. The warm-season grasses, $A$. hallii, $B$. hirsuta, and $S$. cryptandrus, responded positively to mean growing season temperatures (Table 2), responses consistent with our first hypothesis and the four carbon photosynthetic pathway (C4) of these species (Knapp 1985). Indeed, warm-season rhizomatous grasses responded positively to growing season temperatures (Table 3). Positive responses of $R$. arkansana and woody species to mean growing season temperature also were observed. Woody species exhibit plasticity in depth of water uptake relative to warm-season grasses during drought (Eggemeyer et al. 2008), which may contribute to tolerance of higher growing season temperatures.

Although the majority of forbs did not respond to temperature variables, the increase of $A$. psilostachya to increasing mean growing season maximum temperatures is partially supported by Alward et al. (1999) who found forbs increased with increasing minimum growing season temperatures and by Adler and HilleRisLambers (2008) who observed population growth of prairie forbs to be more responsive to changes in mean temperatures than either precipitation or species composition. The increase of $A$. psilostachya with stocking rate also was consistent with previous reports about grazing responses in Sandhills prairie (Reece et al. 2004). On the other hand, we also found forb basal cover to have a negative relationship with the 3-year running mean for total annual precipitation, a result not easily explained. The mechanisms and determinants for why forbs would respond negatively to precipitation amount or not at all as observed by others remain unresolved (Briggs and Knapp 2001), though it is interesting to note that forb basal cover responses were not as closely associated with mean growing season precipitation as the 3-year running mean total precipitation.

Depending on greenhouse gas emission scenarios, recent projections have average temperatures increasing from 1 to 3 _C and winter to spring precipitation increasing 5 to $15 \%$ by 2099 in the central U.S. (US Global Change Research Program 2009; Polley et al. 2013). With increased temperatures, we might expect to find $S$. scoparium and warm-season grasses as a whole continue to account for the majority of basal cover in Sandhills prairie but also observe increased basal cover of woody species such as $R$. arkansana and forbs such as A. psilostachya. Changes in precipitation patterns, on the other hand, would most likely impact basal cover of forbs, warmseason grasses, and cool season grasses as a whole. Nonetheless, despite having long-term observations on basal cover, extrapolating results to predict climatic responses of Sandhills prairie remains difficult due in part to uncertainties associated with future climatic changes and to species-specific responses to climatic and management conditions (Weltzin et al. 2003; Mangan et al. 2004; Adler and HilleRisLambers 2008).

\section{Basal cover, stocking rate, and warm-season grass competition}

With regard to our third hypothesis, we found stocking rate influenced warm-season grass responses, but results were opposite to that which we predicted. We hypothesized basal cover of warm season grasses would decrease with increased stocking rate as heavy grazing intensities have been known to negatively impact basal cover of $S$. scoparium (Butler and Briske 1988; Derner et al. 1994). The use of conservative stocking rates to achieve $50 \%$ rangeland utilization annually in all plots, however, likely did not produce strong enough defoliation intensities to have a negative influence on $S$. scoparium basal cover and, indeed, likely produced defoliation intensities that encourage spread, and therefore, overall greater basal cover of warm season grasses. Increases in basal cover, tiller densities, and frequency of occurrence of perennial warm-season grasses have been observed with light to moderate grazing intensities in the Sandhills (Reece et al. 1988; Stephenson et al. 2013). Implementation 
of heavier grazing intensities where utilization approaches $75 \%$ or more may reduce basal cover of warm-season grasses and contribute to shifting of grassland vegetation from taller to shorter species (Fuhlendorf and Smeins 1997; Fuhlendorf et al. 2001). Indeed, the latter was observed during early years of this study with the shift from $S$. scoparium to $B$. hirsuta dominance (Stubbendieck and Tunnell 2008) when stocking rates averaged 2.2 AUM ha-1 compared to an average of $0.85 \mathrm{AUM} \mathrm{ha}^{-1}$ from 1979 to 2007. As stocking rate increases, both the percentage of tillers defoliated and the number of tillers defoliated multiple times per growing season increase, thereby weakening S. scoparium (Derner et al. 1994).

Lastly, we hypothesized that an increase in basal cover of $S$. scoparium and warm-season grasses as a whole would have a negative effect on basal cover of other species and functional groups. This hypothesis was based on the view that biotic and abiotic processes can regulate population responses to climatic variability (Symstad and Tilman 2001; Adler and HilleRisLambers 2008; Levine et al. 2010). The decline in forb basal cover with the 3-year running mean for total annual precipitation, a response opposite of those grasses, also suggests a potential role of competitive interactions in regulating their dynamics (Briggs and Knapp 2001). Despite their dominance, however, basal cover of $S$. scoparium and warm season grasses as a whole had minimal influence on basal cover of other species and functional groups. This might have been different if species and functional groups responses to S. scoparium and warm-season grasses were evaluated in terms of foliar cover and herbage production; however, current results suggest competition has a weak influence on basal cover in Sandhills prairie. Interestingly, Symstad and Tilman (2001) found S. scoparium increased reproductive output and aboveground biomass but did not respond in terms of recruitment in an experiment in which its competitors were removed suggesting it may itself have minimal influence on other species. Root systems that facilitate water uptake from different depths may be a mechanism by which forbs avoid competition and coexist with dominant warm-season grasses such as $S$. scoparium (Nippert and Knapp 2007). Forb interactions with warmseason grasses also may be more important in terms of recruitment of propagules than in regulating cover of existing plants (Adler and HilleRisLambers 2008).

\section{Conclusions}

Across the 26-year study, results showed that growing season precipitation and temperature, as well as cattle stocking rate, explained the most variability in basal cover responses of individual plant species and functional groups in Sandhills prairie. Stocking rate and lag 3-year growing season precipitation was particularly important to explaining variability of warmseason grasses, which consisted of the majority of total basal cover. The use of light to moderate stocking rates combined with greater precipitation across a few growing seasons would contribute to increased warm season grass and total basal cover, presumably through spread of vegetative structures and enlarging of crowns of bunchgrasses. With regard to forbs and woody plants, subtle deviations from the use of light to moderate stocking rates and growing season precipitation are not likely to have an impact on basal cover of these functional groups, although an increase in stocking rate would promote greater cover of $A$. psilostachya. As a whole, however, understanding of factors that explain forb basal cover in Sandhills prairie remain largely unresolved. Woody species basal cover, on the other hand, would be expected to increase with greater warming in Sandhills prairie. With regard to cool season grasses, they were a smaller component of basal cover in this Sandhills prairie, and similar to that of forbs, we do not have strong conclusions about factors governing their responses, although total precipitation may have a role. Improvement in understanding of variability of cool-season grass basal cover would need further investigation. Lastly, despite their dominance, we found S. scoparium and warmseason grass cover as a whole did not explain basal cover responses of most other species and functional groups, providing weak support for competition as a factor that regulates plant community composition in Sandhills prairie.

Appendix - See Tables 4 and 5. 


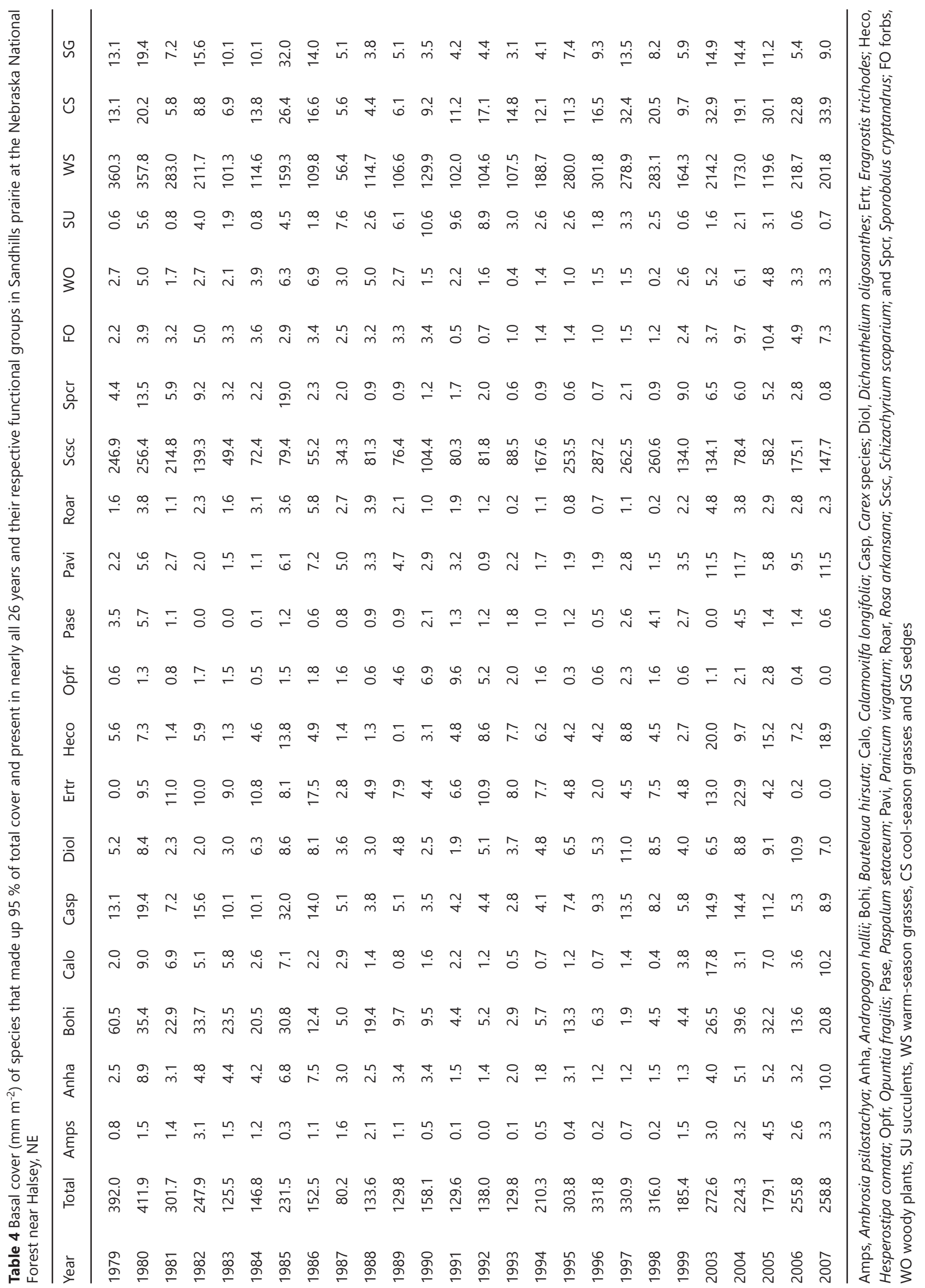




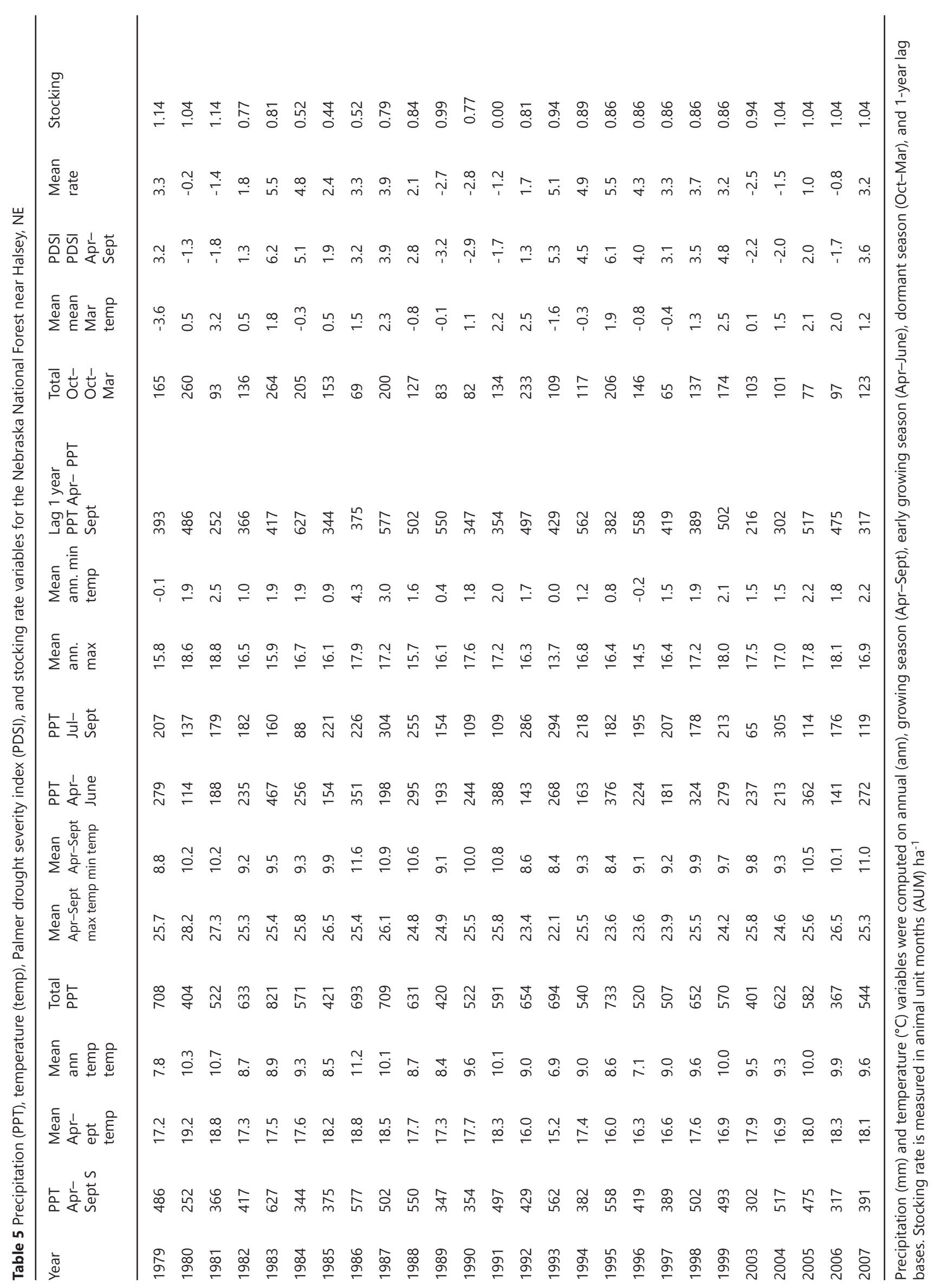




\section{References}

Adler PB, HilleRisLambers J (2008) The influence of climate and species composition on the population dynamics of ten prairie forbs. Ecology 89:3049-306o

Albertson FW, TomanekGW(1965) Vegetation changes during a 30-year period in grassland communities near Hays, Kansas. Ecology 46:714-720

Alward RD, Detling JK, Milchunas DG (1999) Grassland vegetation changes and nocturnal global warming. Science 283:229-231

Benson EJ, Hartnett DC, Mann KH (2004) Belowground bud banks and meristem limitation in tallgrass prairie populations. Am J Bot 91:416-421

Biondini ME, Patton BD, Nyren PE (1998) Grazing intensity and ecosystem processes in a northern mixed-grass prairie, USA. Ecol Appl 8:469-479

Bleed AS, Flowerday CA (1998) Introduction. In: Bleed AS, Flowerday CA (ed) An atlas of the Sand Hills. Resource atlas No. 5b, Conservation and Survey Division, Institute of Agriculture and Natural Resources, University of Nebraska-Lincoln, Lincoln, NE, USA, pp 239-245

Brady WW, Mitchell JE, Bonham CD, Cook JW (1995) Assessing the power of the point-line transect to monitor changes in plant basal cover. J Range Manag 48:187-190

Briggs JM, Knapp AK (2001) Determinants of C3 forb growth and production in $\mathrm{C}_{4}$ dominated grassland. Plant Ecol 152:93-100

Butler JL, Briske DD (1988) Population structure and tiller demography of the bunchgrass Schizachyrium scoparium in response to herbivory. Oikos 51:306-312

Cleland EE, Collins SL, Dickson TL, Farrer EC, Gross KL, Gherardi LA, Hallett LM, Hobbs RJ, Hsu SS, Turnbull L, Suding KN (2013) Sensitivity of grassland plant community composition to spatial vs. temporal variation in precipitation. Ecology 94:1687-1696

Coughenour MB (1985) Graminoid responses to grazing by large herbivores: adaptations, exaptations, and interacting processes. Ann Mo Bot Garden 72:852-863

Cullan AP, Reece PE, Schacht WH (1999) Early summer grazing effects on defoliation and tiller demography of prairie sandreed. J Range Manag 52:447-453

Derner JD, Briske DD (2001) Below-ground carbon and nitrogen accumulation in perennial grasses: a comparison of caespitose and rhizomatous growth forms. Plant Soil 237:117-121

Derner JD, Gillen RL, McCollum FT, Tate KW (1994) Little bluestem tiller defoliation patterns under continuous and rotational grazing. J Range Manag 47:220-225

Easterling DR, Meehl GA, Parmesan C, Changnon SA, Karl TR, Mearns LO (2000) Climate extremes: observations, modeling, and impacts. Sci 289:2068-2074

Eggemeyer KD, Awada T, Harvey FE, Wedin DA, Zhou X, Zanner CW (2008) Seasonal changes in depth of water uptake for encroaching trees Juniperus virginiana and Pinus ponderosa and two dominant $\mathrm{C}_{4}$ grasses in a semiarid grassland. Tree Physiol 29:157-169
Fay PA, Carlisle JD, Danner BT, Lett MS, McCarron JK, Stewart C, Knapp AK, Blair JM, Collins SL (2002) Altered rainfall patterns, gas exchange, and growth in grasses and forbs. Int J Plant Sci 13:549-557

Fay PA, Carlisle JD, Knapp AK, Blair JM, Collins SL (2003) Productivity responses to altered rainfall patterns in a C4- dominated grassland. Oecologia 137:245-251

Fay PA, Kaufman DM, Nippert JB, Carlisle JD, Harper CW (2008) Changes in grassland ecosystem function due to extreme rainfall events: implications for responses to climate change. Global Change Biol 14:16oo-16o8

Fuhlendorf SD, Smeins FE (1997) Long-term vegetation dynamics mediated by herbivores, weather and fire in a Juniperus-Quercus savanna. J Veg Sci 8:819-828

Fuhlendorf SD, Briske DD, Smeins FE (2001) Herbaceous vegetation change in variable rangeland environments: the relative contribution of grazing and climatic variability. Appl Veg Sci 4:177-188

Gillen RL, Sims PL (2006) Stocking rate and weather impacts on sand sagebrush and grasses: a 20-year record. Rangel Ecol Manag 59:145-152

Havstad KM, Herrick JE (2003) Long-term ecological monitoring. Arid Land Res Manag 17:389-400

Heddinghaus TR, Sabol P (1991) A review of the Palmer drought severity index and where do we go from here? In: Proceedings of the 7th conference on applied climatology, American Meteorological Society, Boston, MA, USA, pp 242-246

Heisler-White JL, Knapp AK, Kelly EF (2008) Increasing precipitation event size increases aboveground net primary productivity in a semi-arid grassland. Oecologia 158:129-140

Hendrickson JR, Briske DD (1997) Axillary bud banks of two semiarid perennial grasses: occurrence, longevity, and contribution to population persistence. Oecologia 110:584-591

Herbel CH, Ares FN, Wright RA (1972) Drought effects on a semidesert grassland range. Ecol 53:1084-1093

High Plains Regional Climate Center (2012) Historical climate data summaries. University of Nebraska-Lincoln, Lincoln, NE, USA. http://www.hprcc.unl.edu/data/historical/index. php. Accessed 3 Dec 2013

Hobbs RJ, Yates S, Mooney HA (2007) Long-term data reveal complex dynamics in grassland in relation to climate and disturbance. Ecol Monogr 77:545-568

Hoover DL, Knapp AK, Smith MD (2014) Resistance and resilience of a grassland ecosystem to climate extremes. Ecology 95:2646-2656

Kaul R (1998) Plants. In: Bleed AS, Flowerday CA (ed) An atlas of the Sand Hills. Resource atlas No. 5b, Conservation and Survey Division, Institute of Agriculture and Natural Resources, University of Nebraska-Lincoln, Lincoln, NE, USA, pp 127-142

Keech CF, Bentall R (1971) Dunes on the plains: the Sandhills region of Nebraska. University of Nebraska Conservation and Survey Division, Resource Report 4. Lincoln, Nebraska, USA 
Knapp AK (1985) Effect of fire and drought on the ecophysiology of Andropogon gerardii and Panicum virgatum in a tallgrass prairie. Ecology 66:1309-1320

Knapp AK, Fay PA, Blair JM, Collins SL, Smith MD, Carlisle JD, Harper CW, Danner BT, Lett MS, McCarron JK (2002) Rainfall variability, carbon cycling, and plant species diversity in a mesic grassland. Science 298:2202-2205

Levine JM, McEachern AK, Cowan C (2010) Do competitors modulate rare plant response to precipitation change? Ecology 91:130-140

Mangan JM, Overpeck JT, Webb RW, Wessman C, Goetz AFH (2004) Response of Nebraska Sand Hills natural vegetation to drought, fire, grazing, and plant functional type shifts as simulated by the century model. Clim Change 63:49-90

National Climatic Data Center (2013) US Department of Commerce, NOAA. http://www7.ncdc.noaa.gov/CDO/ CDODivisionalSelect.jsp\#. Accessed 3 Dec 2013

Nippert JB, Knapp AK (2007) Soil water partitioning contributes to species coexistence in tallgrass prairie. Oikos 116:1017-1029

O’Connor TG, Roux PW (1995) Vegetation changes (194971) in a semi-arid, grassy dwarf shrubland in the Karoo, South Africa: influence of rainfall variability and grazing by sheep. J Appl Ecol 32:612-626

Ott JP, Hartnett DC (2011) Bud production and dynamics of flowering and vegetative tillers in Andropogon gerardii (Poaceae): the role of developmental constraints. Am J Bot 98:1293-1298

Polley H, Briske DD, Morgan JA, Wolter K, Bailey DW, Brown JR (2013) Climate change and North American rangelands: trends, projections, and implications. Rangel Ecol Manag 66:493-511

Pool RJ (1913) A study of the vegetation of the Sandhills of Nebraska, Dissertation, University of Nebraska

Reece PE, Bode RP, Waller SS (1988) Vigor of needle and thread and blue grama after short duration grazing. J Range Manag 41:287-291

Reece PE, Brummer JE, Northrup BK, Koehler AE, Moser LE (2004) Interactions among western ragweed and other Sandhill species after drought. Rangel Ecol Manag 57:583-589

Sala OE, Lauenroth WK, Parton WJ (1982) Plant recovery following prolonged drought in a shortgrass steppe. Agric Meteorol 27:49-58

Samson FB, Knopf FL, Ostlie WR (2004) Great Plains ecosystems: past, present, and future. Wildl Soc Bull 32:6-15

Schacht WH, Volesky JD, Bauer D, Smart AJ, Mousel EM (2000) Plant community patterns on upland prairie in the eastern Nebraska Sandhills. Prairie Nat 32:43-58
Sherry RA, Arnone JA III, Johnson DW, Schimel DS, Verburg PS, Luo Y (2012) Carry over from previous year environmental conditions alters dominance hierarchy in a prairie plant community. J Plant Ecol 5:134-146

Smith MD, Knapp AK, Collins SL (2009) A framework for assessing ecosystem dynamics in response to chronic resource alterations induced by global change. Ecology 90:3279-3289

Stephenson MB, Schacht WH, Volesky JD, Eskridge KM, Mousel EM, Bauer D (2013) Grazing method effect on topographical vegetation characteristics and livestock performance in the Nebraska Sandhills. Rangel Ecol Manag $66: 561-569$

Stubbendieck J, Tunnell SJ (2008) Seventy-eight years of vegetation dynamics in a Sandhills grassland. Nat Areas J 28:58-65

Symstad AJ, Tilman D (2001) Diversity loss, recruitment limitation, and ecosystem functioning: lessons learned from a removal experiment. Oikos 92:424-435

Tilman D, El Haddi A (1992) Drought and biodiversity in grasslands. Oecologia 89:257-264

Tilman D, Reich PB, Knops JMH (2006) Biodiversity and ecosystem stability in a decade-long grassland experiment. Nature 441:629-632

Tolstead WL (1942) Vegetation of the northern part of Cherry County, Nebraska. Ecol Monogr 12:255-292

US Forest Service (2009) Updated land and resources management plan for Nebraska national forests and grasslands. http://www.fs.usda.gov/detail/nebraska/landmanagement/ ?cid=FSM9_028050. Accessed 5 Dec 2013

US Global Change Research Program (2009) Global climate change impacts in the United States. In: Karl TR, Melillo JM, Peterson TC (ed) Cambridge University Press, Cambridge. www.globalchange.gov/usimpacts/. Accessed 3 Oct 2013

USDA-NRCS (2016) Ecological site description. Sands medium P.Z. 17-22 P.Z. Provisional. Ro65XY033NE. Major land resource area (MLRA): 065-Nebraska Sand Hills. https://esis.sc.egov.usda.gov/Welcome/pgApprovedSelect. aspx. Accessed 5 May 2016

Weaver JE, Albertson FW (1936) Effects of the great drought on the prairies of Iowa, Nebraska, and Kansas. Ecology 17:567-639

Weltzin JF, Loik ME, Schwinning S, Williams DG, Fay PA, Haddad BM, Harte J, Huxman TE, Knapp AK, Lin G, Pockman WT, Shaw MR, Small EE, Smith ME, Smith SD, Tissue DT, Zak JC (2003) Assessing the response of terrestrial ecosystems to potential changes in precipitation. Bioscience 53:941-995 